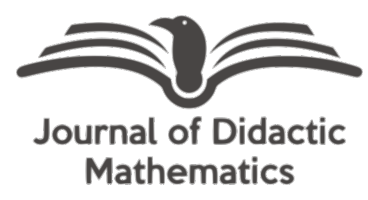

\title{
Analisis kemampuan berpikir kritis matematis ditinjau dari resiliensi matematis mahasiswa pendidikan teknik informatika dan komputer
}

\author{
Ade Evi Fatimah* \\ STKIP Al Maksum, Langkat, Sumatera Utara, Indonesia, 20814
}

\section{Fitriani}

Universitas Muhammadiyah Tapanuli Selatan, Padangsidimpuan, Sumatera Utara, Indonesia, 22716

*Corresponding Author: adeevifatimah@stkipalmaksum.ac.id

\begin{abstract}
This study aims to determine the students' mathematical critical thinking abilities in terms of their mathematical resilience. The subjects of this study were students of Informatics and Computer Engineering Education STKIP Al Maksum in discrete mathematics courses, totaling 37 students. The research instrument used in the form of mathematical critical thinking ability test questions and student mathematical resilience questionnaires. The research method used is a correlational method with a quantitative approach. Then the data were analyzed using simple linear regression. The results showed that the mathematical critical thinking ability based on the mathematical resilience of the students of the Computer Informatics Engineering Education Study Program, STKIP Al Maksum, had a positive effect of $79.9 \%$.
\end{abstract}

Historis Artikel:

Diterima: 19 Juli 2021

Direvisi: 2 September 2021

Disetujui: 8 September 2021

\section{Keywords:}

Mathematical critical thinking; mathematical resilience.

Sitasi: Fatimah, A. E., \& Fitriani, F. (2021). Analisis kemampuan berpikir kritis matematis ditinjau dari resiliensi matematis mahasiswa pendidikan teknik informatika dan komputer. Journal of Didactic Mathematics, 2(2), 94-100. Doi: $10.34007 / \mathrm{jdm} . v 2 \mathrm{i} 2.871$

\section{PENDAHULUAN}

Tuntutan pendidikan di era revolusi industri 4.0 saat ini mewajibkan para pendidik melengkapi peserta didiknya dengan keterampilan-keterampilan yang bisa digunakan dalam berkompetisi dengan masyarakat global. Salah satunya adalah keterampilan matematika. Keterampilan matematika dapat diajarkan kepada peserta didik melalui proses pembelajaran matematika di seluruh tingkat satuan pendidikan, tidak terkecuali di perguruan tinggi. Menurut Murtiyasa (2016) keterampilan matematika abad 21 mencakup empat keterampilan, yaitu kreativitas (creativity), kemampuan berpikir kritis (critical thinking), berkomunikasi (communication), dan berkolaborasi (collaboration), yang lebih dikenal dengan akronim 'Four Cs (4C)'. Hal ini menunjukkan bahwa diharapkan dengan adanya proses pembelajaran matematika, maka akan tercipta sumber daya manusia yang handal dan siap berkompetisi, yaitu SDM yang kreatif, mampu berpikir kritis, berkomunikasi dan berkolaborasi.

Fokus kepada aspek kemampuan berpikir kritis, aspek ini merupakan salah satu aspek yang sangat penting dalam pembelajaran matematika. Marcut (2005) menyatakan bahwa mempromosikan pemikiran kritis dan pemecahan masalah dalam pendidikan matematika sangat penting dalam pengembangan siswa yang sukses. Berpikir kritis dan pemecahan masalah berjalan beriringan. Untuk mempelajari matematika melalui pemecahan masalah, siswa juga harus belajar bagaimana berpikir kritis. Hal ini juga berlaku pada pembelajaran matematika di perguruan tinggi, khususnya pada mata kuliah matematika diskrit. Pembelajaran mata kuliah matematika diskrit hendaknya menjadi aktivitas untuk melatih kemampuan berpikir kritis mahasiswa, karena kemampuan berpikir kritis bukan merupakan kemampuan yang dibawa sejak lahir dan juga tidak 
Analisis kemampuan berpikir kritis matematis ditinjau dari resiliensi...

berkembang secara alami. Kemampuan berpikir kritis merupakan potensi intelektual yang dapat dikembangkan melalui proses pembelajaran (Cahyono, 2017).

Fatimah et al. (2020) menyatakan bahwa pembelajaran matematika bertujuan untuk membentuk pola pikir mahasiswa yang logis, kritis, dan sistematis serta memiliki kejujuran dan rasa percaya diri dalam mengungkapkan pendapatnya agar mampu mengatasi kesulitan dan memecahkan berbagai permasalahan. Kemudian Zetriuslita et al. (2016) menyatakan bahwa kemampuan berpikir kritis dapat membuat dan melatih seseorang untuk melakukan (doing math) dalam pembelajaran matematika. Selain itu, Nugraha et al. (2017) mengatakan bahwa kemampuan berpikir kritis merupakan kunci kompetensi yang harus dimiliki untuk memecahkan masalah yang diperlukan bagi individu untuk hidup sukses dan hidup bertanggung jawab dan bagi masyarakat untuk menghadapi tantangan masa kini dan masa depan. Selanjutnya Yunita et al. (2018) menyatakan berpikir kritis merupakan kegiatan yang masuk akal dan berorientasi pada tujuan untuk menganalisis, membedakan secara tajam, mengidentifikasi, mengkaji, dan mengembangkan suatu informasi atau ide kearah yang lebih sempurna. Sehingga dapat disimpulkan bahwa kemampuan berpikir kritis merupakan salah satu kompetensi bernalar dan berpikir secara sistemik yang diperlukan untuk menganalisis, membedakan secara tajam, mengidentifikasi, mengkaji, dan mengembangkan suatu informasi atau ide dalam menyelesaikan suatu masalah. Sumarmo (Yunita et al., 2018) menyatakan terdapat lima indikator kemampuan berpikir kritis, yaitu a) memeriksa kebenaran argumen, pernyataan dan proses solusi, b) menyusun pertanyaan disertai alasan, c) mengidentifikasi data relevan dan tidak relevan suatu masalah matematika, d) mengidentifikasi asumsi, dan e) menyusun jawaban/menyelesaiakn masalah matematika disertai alasan.

Lebih lanjut Marlina (2018) menyatakan berpikir kritis dicirikan dengan: bertanya secara jelas dan beralasan, berusaha memahami dengan baik, menggunakan sumber yang terpercaya, mempertimbangkan situasi secara keseluruhan, berusaha tetap mengacu dan relevan ke masalah pokok, mencari berbagai alternatif, bersikap terbuka, berani mengambil posisi, bertindak cepat, bersikap atau berpandangan bahwa sesuatu adalah bagian dari keseluruhan yang kompleks, memanfaatkan cara berpikir kritis orang lain yang kritis, dan bersikap sensitif terhadap perasaan orang lain. Dari beberapa ciri-ciri tersebut, seperti berusaha memahami masalah dengan baik, berusaha mencari berbagai alternatif penyelesaian, bersikap terbuka, dan berani mengambil posisi adalah juga merupakan ciri-ciri kemampuan resiliensi. Kemampuan resiliensi dalam proses pembelajaran matematika disebut kemampuan resiliensi matematis.

Johnston-Wilder (2010) menyatakan bahwa mahasiswa yang memiliki resiliensi matematis akan bertahan saat menghadapi kesulitan, akan berhasil secara kolaboratif dengan teman sebayanya, akan memiliki keterampilan bahasa yang dibutuhkan untuk mengekspresikan pemahaman dan akan memiliki teori pembelajaran yang berkembang. Goodall (2015) menyatakan bahwa mahasiswa dengan kemampuan mathematical resilience, maka dia akan memiliki keyakinan bahwa kemampuan mereka dalam matematika akan berkembang. Kemudian Sugandi (2017) adalah sikap berkualitas dalam pembelajaran matematika yang meliputi percaya diri melalui usaha keras akan keberhasilan, memperlihatkan ketekunan dalam menemukan kesulitan, mempunyai keinginan untuk berdiskusi, mencerminkan, dan melakukan penelitian. Sumarmo (2018) menyatakan bahwa resiliensi matematis memuat sikap tekun atau tangguh dalam menghadapi kesulitan, bekerja atau belajar kolaboratif dengan teman sebaya, memiliki keterampilan berbahasa untuk menyatakan pemahaman matematik, dan menguasai teori belajar matematika. Selanjutnya Fatimah dan Purba (2021) menyatakan bahwa mahasiswa yang memiliki resiliensi matematis adalah mahasiswa yang mampu beradaptasi dalam setiap kondisi, memiliki rasa sadar akan kemampuannya, yakin, dan percaya diri bahwa mereka juga memahami apa yang orang lain pahami dan mampu menghadapi dan menyelesaikan permasalahan atau hambatan dalam pembelajaran matematika, serta mampu memberikan solusi yang tepat hingga akhirnya mereka akan sukses. Mahasiswa dengan ketahanan yang kuat akan memiliki keterampilan matematika yang diperlukan dalam pembelajaran matematika, salah satunya keterampilan berpikir kritis. Ansori (2020) Pengembangan ketahanan matematika juga membutuhkan sikap kritis terhadap pembelajaran matematika, mahasiswa mampu 
merefleksikan pengetahuan yang diperoleh serta membaca ide-ide dan menghubungkan dengan konsep satu dengan yang lainnya. Oleh karena itu dapat dilihat bahwa kemampuan berpikir kritis seorang mahasiswa dalam pembelajaran matematika berkaitan dengan kemampuan resiliensi matematisnya.

Pada kenyataannya di STKIP Al Maksum masih banyak mahasiswa yang menganggap pembelajaran matematika khususnya mata kuliah matematika diskrit adalah mata kuliah yang sangat sulit dipecahkan. Mahasiswa masih kurang tekun dan kurang percaya diri dalam menyelesaikan permasalahan-permasalahan yang diberikan. Dengan kemampuan berpikir kritis matematis yang baik mahasiswa akan dapat memahami situasi yang membutuhkan aplikasi/penerapan matematika sebagai solusi. Mahasiswa tidak hanya memandang materi yang dipelajari hanya sebatas memahami definisi dan membuktikan teorema semata, akan tetapi dapat mengaktualisasikan penerapannya dalam masalah yang membutuhkan solusi konkrit. Namun faktanya dalam menyelesaikan permasalahan yang berkaitan dengan kemampuan berpikir kritis matematis, masih sering ditemukan beberapa kesalahan sehingga diperlukannya analisis kemampuan berpikir kritis matematis yang dilihat dari resiliensi matematis mahasiswa.

Sejauh ini penelitian yang bertujuan untuk mendeskripsikan peningkatan kemampuan berpikir kritis ditinjau dari resiliensi matematis mahasiswa masih sangat sedikit. Peneliti-peneliti terdahulu hanya melihat kemampuan berpikir kritis ditinjau dari kemampuan yang lain, seperti penelitian yang dilakukan oleh Nugraha et al. (2017) yang menyatakan bahwa keterampilan proses sains mempengaruhi kemampuan berpikir kritis sebesar 41,5\% dan motivasi belajar mempengaruhi kemampuan berpikir kritis sebesar 94,5\%. Selanjutnya penelitian yang dilakukan oleh Yunita et al. (2018) yang menyatakan bahwa kemampuan berpikir kritis matematis berdasarkan motivasi belajar pada siswa SMP memiliki pengaruh positif sebesar $16,2 \%$. Selain itu ada juga penelitian yang bertujuan untuk mendeskripsikan kemampuan resiliensi matematis dalam meningkatkan kemampuan yang lain, seperti penelitian yang dilakukan oleh Ansori (2020) yang menyatakan bahwa siswa yang memiliki tingkat reseliensi yang baik akan berpengaruh positif dalam kemampuan koneksi matematika. Selanjutnya penelitian yang dilakukan oleh Permatasari et al. (2021) yang menyatakan bahwa terdapat pengaruh positif kemandirian belajar terhadap mathematical resilience mahasiswa dan kedua variabel memiliki hubungan yang kuat. Oleh karena itu, berdasarkan beberapa hasil penelitian tersebut, maka penulis ingin melakukan penelitian untuk mengetahui kemampuan berpikir kritis matematis ditinjau dari kemampuan resiliensi matematis mahasiswa Prodi Pendidikan Teknologi Informatika dan Komputer STKIP Al Maksum.

\section{METODE}

Tujuan penelitian ini adalah untuk mengetahui kemampuan berpikir kritis matematis ditinjau dari kemampuan resiliensi matematis mahasiswa. Metode dalam penelitian ini menggunakan metode korelasional dengan pendekatan kuantitatif. Data hasil penelitian diolah dan dianalisis menggunakan uji statistika regresi linear. Populasi dalam penelitian ini adalah seluruh mahasiswa semester IV (empat) tahun ajaran 2020-2021 dengan sampel berjumlah 37 orang. Instrumen dalam penelitian ini menggunakan soal tes kemampuan berpikir kritis matematis bentuk uraian yang terdiri dari lima butir soal dan non tesnya berupa skala resiliensi matematis yang terdiri dari 25 pernyataan serta dilengkapi dengan 4 pilihan jawaban, yaitu Sering sekali (SS), Sering (S), Jarang (J) dan Jarang Sekali (JS). Angket resiliensi matematis diukur dengan menggunakan skala likert. Sugiyono (2018) mengatakan skala likert digunakan untuk mengukur sikap, pendapat, dan persepsi seseorang atau sekelompok orang tentang fenomena sosial. Untuk mennentukan besarnya hubungan antar variabel, interpretasinya mengacu pada Tabel 1 berikut. 
Analisis kemampuan berpikir kritis matematis ditinjau dari resiliensi...

Tabel 1. Interpretasi koefisien korelasi (Sugiyono, 2018)

$$
\begin{gathered}
\text { Nilai R } \\
0,00-0,199 \\
0,20-0,399 \\
0,40-0,599 \\
0,60-0,799 \\
0,80-1
\end{gathered}
$$

\author{
Interpretasi \\ Sangat rendah \\ Rendah \\ Sedang \\ Kuat \\ Sangat kuat
}

\section{HASIL DAN PEMBAHASAN}

Tujuan utama penelitian ini adalah untuk mengetahui kemampuan berpikir kritis matematis ditinjau dari kemampuan resiliensi matematis mahasiswa pada mata kuliah matematika diskrit. Data yang diperoleh dari hasil ujicoba instrumen telah dianalisis bahwa kemampuan berpikir kritis

\begin{tabular}{|c|c|c|c|c|c|c|c|}
\hline & & & Sum of Squares & $\mathrm{df}$ & Mean Square & $\mathrm{F}$ & Sig. \\
\hline \multirow{6}{*}{$\begin{array}{c}\text { KBK* } \\
\text { RM }\end{array}$} & \multirow{3}{*}{$\begin{array}{c}\text { Between } \\
\text { Groups }\end{array}$} & (Combined) & 5606.568 & 24 & 233.607 & 4.429 & .005 \\
\hline & & Linearity & 4985.594 & 1 & 4985.594 & 94.514 & .000 \\
\hline & & $\begin{array}{l}\text { Deviation } \\
\text { from }\end{array}$ & 620074 & 23 & 26000 & 512 & 019 \\
\hline & & Linearity & 020.914 & 23 & 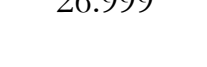 & .512 & \\
\hline & \multicolumn{2}{|c|}{ Within Groups } & 633.000 & 12 & 52.750 & & \\
\hline & \multicolumn{2}{|c|}{ Total } & 6239.568 & 36 & & & \\
\hline
\end{tabular}
matematis dan resiliensi matematis mahasiswa berdistribusi normal. Selanjutnya dilakukan uji linearilitas kemampuan berpikir kritis matematis dan resiliensi matematis mahasiswa dengan hasil pengujian pada Tabel 2 di bawah ini.

Tabel 2. Uji Linearitas Kemampuan Berpikir Kritis Matematis Berdasarkan Resiliensi Matematis Mahasiswa

Berdasarkan hasil uji linearitas kemampuan berpikir kritis matematis dan resiliensi matematis mahasiswa pada Tabel 2, dapat dilihat bahwa nilai Sig. pada Deviation from Linearity adalah sebesar 0,919. Jika (Sig. $>\alpha=0,05$ ) maka hal ini mengartikan bahwa kemampuan berpikir kritis matematis dan resiliensi matematis mahasiswa mempunyai hubungan yang linear. Dengan kata lain

\begin{tabular}{|c|c|c|c|c|c|c|}
\hline & del & Sum of Squares & $\mathrm{df}$ & Mean Square & $\mathrm{F}$ & Sig. \\
\hline \multirow{3}{*}{1} & Regression & 4985.594 & 1 & 4985.594 & 139.154 & $.000^{\mathrm{b}}$ \\
\hline & Residual & 1253.974 & 35 & 35.828 & & \\
\hline & Total & 6239.568 & 36 & & & \\
\hline
\end{tabular}
hubungan antara variabel bersifat linier, dimana perubahan pada variabel resiliensi matematis akan diikuti oleh perubahan pada variabel kemampuan berpikir kritis secara tetap.

Selanjutnya, dilakukan uji regresi (dapat dilijhat pada Tabel 3) untuk melihat apakah terdapat pengaruh pada kemampuan berpikir kritis matematis berdasarkan resiliensi matematis mahasiswa.

Tabel 3. Uji Regresi Kemampuan Berpikir Kritis dan Resiliensi Matematis Mahasiswa

Berdasarkan hasil uji regresi pada Tabel 3 dapat terlihat bahwa nilai Sig. Regression sebesar 0,000. Jika (Sig. $<\alpha=0,05$ ) maka hal ini mengartikan bahwa terdapat pengaruh positif antara kemampuan berpikir kritis dan resiliensi matematis mahasiswa. Kemudian untuk melihat besar pengaruh yang diberikan resiliensi matematis terhadap kemampuan berpikir kritis mahasiswa dapat dilihat pada Tabel 4 berikut.

Tabel 4. Model Summary

\begin{tabular}{ccccc} 
Model & $\mathrm{R}$ & R Square & Adjusted R Square & Std. Error of the Estimate \\
\hline 1 & $.894^{a}$ & .799 & .793 & 5.986 \\
\hline
\end{tabular}


Berdasarkan Tabel 4 dapat terlihat koefisien korelasi pada kolom $\mathrm{R}$ sebesar 0,894, hal ini menunjukkan bahwa terdapat pengaruh yang sangat kuat antara resiliensi matematis dengan kemampuan berpikir kritis matematis. Sedangkan nilai koefisien determinasi pada kolom $R$ Square sebesar 0,799. Hal ini dapat diartikan bahwa besar pengaruh resiliensi matematis terhadap kemampuan berpikir kritis mahasiswa adalah $79,9 \%$.

Tabel 5. Koefisien Regresi

\begin{tabular}{|c|c|c|c|c|c|c|}
\hline \multirow[t]{2}{*}{ Model } & & \multicolumn{2}{|c|}{ Unstandardized Coefficients } & \multirow{2}{*}{$\begin{array}{l}\text { Standardized Coefficients } \\
\text { Beta }\end{array}$} & \multirow[t]{2}{*}{$\mathrm{T}$} & \multirow[t]{2}{*}{ Sig. } \\
\hline & & B & Std. Error & & & \\
\hline & (Constant) & -10.652 & 6.246 & & -1.705 & .097 \\
\hline 1 & $\begin{array}{l}\text { Resiliensi } \\
\text { Matematis }\end{array}$ & 1.015 & .086 & .894 & 11.796 & .000 \\
\hline
\end{tabular}

Berdasarkan Tabel 5 dapat dilihat pada kolom B mengenai persamaan regresinya pada kemampuan berpikir kritis matematis berdasarkan resiliensi matematis adalah $\mathrm{Y}=-10,652+1$, 015X. Berdasarkan persamaan ini dapat dimaknai bahwa konstanta (a) sebesar -10,652 artinya jika resiliensi matematis bernilai 0 maka kemampuan berpikir kritis matematis mahasiswa bernilai negative 10,652, dan koefisien regresi $X$ resiliensi matematis sebesar 1,015 hal ini menyatakan bahwa setiap penambahan 1 nilai resiliensi matematis maka nilai kemampuan berpikir kritis matematis bertambah sebesar 1,015.

Berdasarkan hasil penelitian terlihat bahwa terdapat pengaruh yang positif pada kemampuan berpikir kritis matematis berdasarkan resiliensi matematis mahasiswa, pengaruh yang positif tersebut dapat dilihat dari resiliensi matematis mahasiswa dalam menyelesaikan soal uraian kemampuan berpikir kritis matematis. Skor maksimal kemampuan berpikir kritis matematis pada penelitian ini adalah 84. Mahasiswa yang mendapatkan nilai tertinggi dalam tes kemampuan berpikir kritis matematis berdasarkan resiliensi matematis diambil dari empat teratas, yaitu mahasiswa dengan kode M-37, M-33, M-34, dan M-23.

Tabel 6. Nilai tertinggi kemampuan berpikir kritis matematis berdasarkan resiliensi matematis mahasiswa

\begin{tabular}{cccc}
\hline No. & Kode Mahasiswa & Skor Resiliensi Matematis & Skor Kemampuan Berpikir Kritis \\
\hline 1 & M-37 & 90 & 84 \\
2 & M-33 & 89 & 82 \\
3 & M-34 & 86 & 80 \\
4 & M-23 & 82 & 64 \\
Rata-rata & & & 78 \\
\hline
\end{tabular}

Hasil penelitian menunjukkan bahwa keempat mahasiswa dengan kode M-37, M-33, M-34, dan M-23 mendapatkan nilai tertinggi pada tes kemampuan berpikir kritis berdasarkan resiliensi matematis. Keempat mahasiswa tersebut sudah menunjukkan ketuntasan pada kelima indikator pada masing-masing tahapan kemampuan berpikir kritis, yaitu sudah mampu memeriksa kebenaran argumen, pernyataan, dan proses solusi, mampu menyusun pertanyaan disertai alasan, mampu mengidentifikasi data relevan dan tidak relevan dari suatu masalah matematika, mampu mengidentifikasi asumsi, dan mampu menyusun jawaban atau menyelesaikan masalah matematika disertai alasan. Oleh karena itu dapat dikatakan bahwa berdasarkan resiliensi matematis keempat mahasiswa tersebut memiliki kemampuan berpikir kritis matematis yang sangat baik dalam menelaah permasalahan hingga menyelesaikan permasalahan disertai dengan alasan yang tepat. Sehingga dapat dilihat bahwa resiliensi matematis mahasiswa dapat berpengaruh positif terhadap kemampuan berpikir kritis mahasiswa. Hal ini sejalan dengan penelitian Zanthy (2018) yang menyatakan bahwa terdapat hubungan yang positif dan signifikan antara resiliensi matematis dengan kemampuan akademik mahasiswa yang artinya resiliensi matematis dapat digunakan untuk memprediksikan tingkat kemampuan akademik mahasiswa. Kemudian Iman (2019) yang 
Analisis kemampuan berpikir kritis matematis ditinjau dari resiliensi...

menyatakan bahwa kemampuan resiliensi matematis juga ikut memegang andil dalam mempengaruhi hasil belajar matematika siswa, dimana apabila kemampuan resiliensi matematis siswa tinggi maka hasil belajar siswa tersebut juga akan tinggi. Ansori (2020) dalam penelitiannya menyimpulkan bahwa siswa yang mempunyai resiliensi yang tinggi mampu menjawab tes dengan baik. Selanjutnya Rahmmatiya (2020) dalam penelitiannya menyatakan bahwa subjek yang memiliki resiliensi tinggi mampu mengerjakan tes kemampuan pemecahan masalah dengan baik dan percaya diri dalam menjawab setiap pertanyaannya.

\section{KESIMPULAN}

Berdasarkan hasil dan pembahasan yang telah disajikan, maka dapat disimpulkan bahwa kemampuan berpikir kritis matematis berdasarkan resiliensi matematis mahasiswa prodi Pendidikan Teknik Informatika Komputer STKIP Al Maksum memiliki pengaruh positif sebesar $79,9 \%$. Sedangkan $20,1 \%$ di pengaruhi oleh faktor selain dari resiliensi matematis mahasiswa.

\section{DAFTAR PUSTAKA}

Ansori., \& Hindriyanto. (2020). Analisis kemampuan koneksi ditinjau berdasarkan kemampuan resiliensi matematis siswa. JKPM (Jurnal Kajian Pendidikan Matematika), 5(2), 253-262.

Cahyono, B. (2017). Analisis ketrampilan berfikir kritis dalam memecahkan masalah ditinjau perbedaan gender. Aksioma: Jurnal Matematika dan Pendidikan Matematika, 8(1), 50-64. https://doi.org/10.26877/aks.v8i1.1510

Fatimah, A. E., Purba, A., \& Siregar, Y. A. (2020). Hubungan resiliensi matematis terhadap kemampuan pemecahan masalah matematis mahasiswa pada mata kuliah Matematika dasar. Journal of Didactic Mathematics, 1(3), 151-157. https://doi.org/10.34007/jdm.v1i3.470

Fatimah, A. E., \& Purba, A. (2021). Meningkatkan resiliensi matematis mahasiswa pada mata kuliah matematika dasar melalui pendekatan differentiated instruction. Journal of Didactic Mathematics, 2(1), 42-49. https://doi.org/10.34007/jdm.v2i1.617

Goodall, J., \& Johnston-Wilder, S. (2015). Overcoming mathematical helplessness and developing mathematical resilience in parents: An illustrative case study. Creative Education, 6, 526-535. Doi: $10.4236 /$ ce.2015.65052

Iman, S. A., \& Firmansyah, D. (2019). Pengaruh kemampuan resiliensi matematis terhadap hasil belajar matematika. Prosiding Seminar Nasional Matematika dan Pendidikan Matematika Sesiomadika. 356-360.

Johnston-Wilder, S., \& Lee, C. (2010). Developing mathematical resilience. In: BERA Annual Conference 2010, 1-4 Sep 2010, University of Warwick.

Marlina, E., \& Harahap, E. (2018). Mengembangkan kemampuan berpikir kritis dan resiliensi matematik melalui pembelajaran program linier berbantuan qm for windows. Matematika: Jurnal Teori dan Terapan Matematika, 17(2), 59-70. https://doi.org/10.29313/jmtm.v17i2.4431

Marcut, I. (2005). Critical thinking - applied to the methodology of teaching mathematics. Educatia Matematica, 1(1), 57-66.

Murtiyasa, B. (2016). Isu-isu kunci dan tren penelitian pendidikan matematika. Prosiding Konferensi Nasional Penelitian Matematika dan Pembelajarannya (KNPMP I), Surakarta: 12 Maret 2016.

Nugraha, A. J., Suyitno, H., \& Susilaningsih, E. (2017). Analisis kemampuan berpikir kritis ditinjau dari keterampilan proses sains dan motivasi belajar melalui model pbl. Journal of Primary Education, 6(1), 35-43. Doi: 10.15294/JPE.V6I1.14511

Permatasari, D., Maziyah, K., \& Fadila, R. (2021). Pengaruh kemandirian belajar terhadap mathematical resilience mahasiswa dalam pembelajaran daring. Jurnal Cendekia : Jurnal Pendidikan Matematika, 5(1), 249-258. https://doi.org/10.31004/cendekia.v5i1.479

Rahmmatiya, R., \& Miatun, A. (2020). Analisis kemampuan pemecahan masalah matematis ditinjau dari resiliensi matematis siswa smp. Teorema: Teori dan Riset Matematika, 5(2), 187-202. http://dx.doi.org/10.25157/teorema.v5i2.3619 
Sugandi, A. I. (2017). Meningkatkan kemampuan berpikir kreatif dan resiliensi matematis siswa smp melalui pendekatan generatif. Jurnal Perspektif Pendidikan, 11(2), 67-77.

Sugiyono. (2018). Metode penelitian pendidikan pendekatan kuantitaitif, kualitatif, dan R\&D. Bandung: Alfabeta.

Sumarmo, U. (2018). Hardskill dan softskill matematika serta kearifan lokal dalam pembelajaran matematika. Proceeding National Seminar of Mathematics Education Unswagati Cirebon. Cirebon.

Yunita, N., Rosyana, T., \& Hendriana, H. (2018). Analisis kemampuan berpikir kritis matematis berdasarkan motivasi belajar matematis siswa smp. JPMI : Jurnal Pembelajaran Matematika Inovatif, 1(3), 325-332. http://dx.doi.org/10.22460/jpmi.v1i3.p325-332

Zanthy, L. S. (2018). Kontribusi Resiliensi Matematis terhadap Kemampuan Akademik Mahasiswa pada Mata Kuliah statistika Matematika. Jurnal Mosharafa, 7(1), 85-94.

Zetriuslita, Z., Ariawan, R., \& Nufus, H. (2016). Analisis kemampuan berpikir kritis matematis mahasiswa dalam menyelesaikan soal uraian kalkulus integral berdasarkan level kemampuan mahasiswa. Infinity Journal, 5(1), 56-66. http://dx.doi.org/10.22460/infinity.v5i1.p56-66 